\title{
Silvestrol exhibits significant in vivo and in vitro antileukemic activities and inhibits FLT3 and miR-155 expressions in acute myeloid leukemia
}

Houda Alachkar1,4, Ramasamy Santhanam 1,4, Jason G Harb²,4, David M Lucas ${ }^{1,4}$, Joshua J Oaks 2,4, Christopher J Hickey ${ }^{1,4}$, Li Pan ${ }^{3}$, A Douglas Kinghorn ${ }^{3}$, Michael A Caligiuri ${ }^{1,4}$, Danilo Perrotti ${ }^{2,4}$, John C Byrd ${ }^{1,4}$, Ramiro Garzon ${ }^{1,4}$, Michael R Grever ${ }^{1,4,6^{*}+}$ and Guido Marcucci ${ }^{1,4,5^{*}+}$

\begin{abstract}
Background: Activating mutations [internal tandem duplication (ITD)] or overexpression of the FMS-like tyrosine kinase receptor-3 (FLT3) gene are associated with poor outcome in acute myeloid leukemia (AML) patients, underscoring the need for novel therapeutic approaches. The natural product silvestrol has potent antitumor activity in several malignancies, but its therapeutic impact on distinct molecular high-risk AML subsets remains to be fully investigated. We examined here the preclinical activity of silvestrol in FLT3-ITD and FLT3 wild-type (wt) AML.

Methods: Silvestrol in vitro anti-leukemic activity was examined by colorimetric cell viability assay, colony-forming and flow cytometry assays assessing growth inhibition and apoptosis, respectively. Pharmacological activity of silvestrol on FLT3 mRNA translation, mRNA and protein expression was determined by RNA-immunoprecipitation, qRT-PCR and immunoblot analyses, respectively. Silvestrol in vivo efficacy was investigated using MV4-11 leukemiaengrafted mice.
\end{abstract}

Results: Silvestrol shows antileukemia activity at nanomolar concentrations both in FLT3-wt overexpressing (THP-1) and FLT3-ITD (MV4-11) expressing AML cell lines ( $\mathrm{IC}_{50}=3.8$ and $2.7 \mathrm{nM}$, respectively) and patients' primary blasts $\left[\mathrm{C}_{50}=\sim 12 \mathrm{nM}\right.$ (FLT3-wt) and $\sim 5 \mathrm{nM}$ (FLT3-ITD)]. Silvestrol increased apoptosis ( 4fold, $\left.\mathrm{P}=0.0001\right)$, and inhibited colony-formation $(100 \%, P<0.0001)$ in primary blasts. Silvestrol efficiently inhibited FLT3 translation reducing FLT3 protein expression by $80-90 \%$ and decreased miR-155 levels ( 60\%), a frequently co-regulated onco-miR in FLT3ITD-positive AML. The median survival of silvestrol-treated vs vehicle-treated mice was 63 vs 29 days postengraftment, respectively $(P<0.0001)$.

Conclusions: Silvestrol exhibits significant in vivo and in vitro antileukemic activities in AML through a novel mechanism resulting in inhibition of FLT3 and miR-155 expression. These encouraging results warrant a rapid translation of silvestrol for clinical testing in AML.

\section{Background}

Acute myeloid leukemia (AML) is one of the most common types of leukemia. Today, only $40 \%$ of younger (age $<60$ years) and $10 \%$ of older (age $\geq 60$ years) adults with AML treated with conventional chemotherapy achieve

\footnotetext{
* Correspondence: michael.grever@osumc.edu; guido.marcucci@osumc.edu ${ }^{\dagger}$ Equal contributors

'Division of Hematology, Department of Medicine, The Ohio State University, Columbus, OH, USA

${ }^{4}$ Comprehensive Cancer Center, The Ohio State University, Columbus, $\mathrm{OH}$, USA

Full list of author information is available at the end of the article
}

long-term survival [1]. The outcome for high-risk patients who are treated with allogeneic stem cell transplantation in first complete remission are encouraging, but lack of suitable donors, presence of co-morbidities and treatment-related toxicity and mortality has often limited the application of this approach. Therefore, novel therapeutic strategies that improve the currently poor outcome in AML patients while demonstrating an optimal toxicity index are highly needed.

Recurrent cytogenetics and molecular aberrations are known to impact the prognosis of AML. Importantly,

\section{Biomed Central}


several of these genomic aberrations may also constitute novel therapeutic targets. Gain-of-function mutations of the tyrosine kinase (TK) receptor encoding gene FLT3 occur in approximately $30 \%$ of AML patients, and result in constitutive TK activity and, in turn, increasing growth and survival of leukemia blasts [2]. Of the FLT3 mutations, the internal tandem duplication (FLT3-ITD) is associated with poorer outcome [3-8]. In addition, overexpression of the FLT3-wt receptor and its ligand (FL) occurs in a high percentage of AML and the subsequent autocrine stimulatory loop may contribute to the pathogenesis and aggressiveness of the disease $[9,10]$. Therefore, investigating compounds that can inhibit both mutant and overexpressed wild type FLT3 in AML leukemia is warranted.

Smith et al. demonstrated that FLT3-ITD likely constitutes a driver mutation in AML and therefore it may represent not only as a prognosticator but also a potential therapeutic target [11]. Emerging small molecule inhibitor compounds have been shown to interfere with the aberrant FLT3 TK activity and lead to arrest of leukemia growth $[6,12]$. Unfortunately the clinical impact of these compounds as single agents or in combination with chemotherapy has not yet fulfilled the promise, likely because of their relatively low potency, lack of specificity and the early onset of mechanisms of resistance [13-15]. This underscores the need for additional strategies that effectively target aberrant FLT3 activity in AML blasts and improve the currently poor survival rate in high-risk patients with FLT3-driven AML.

Silvestrol is a cyclopenta $[b]$ benzofuran rocaglate with a unique dioxanyl ring-containing side chain $[16,17]$. It was isolated from the Indonesian plant Aglaia foveolata, structurally characterized, and tested for anti-tumor efficacy [16]. Silvestrol showed activity against several solid tumor cell lines [18-21] as well as primary chronic lymphocytic leukemia cells at nanomolar concentrations, and prolonged survival in a murine model of B cell acute lymphoblastic leukemia [22]. More recently, silvestrol was reported to have synergistic activity against AML cell lines when combined with chemotherapy [23]. Pelletier et al., demonstrated that silvestrol interferes with assembly of the eIF4F translation complex by promoting an aberrant interaction between capped mRNA and eIF4A, thus blocking protein synthesis at the initiation step $[21,24]$. This inhibition of protein synthesis results in a preferential depletion of proteins with short half-lives, such as MCL1, to which leukemia and cancer cells may be addicted and thrive on [22,24]. Therefore, we hypothesize that silvestrol could also inhibit translation of FLT3 mRNA and in turn downregulate the expression of FLT3 and decrease aberrant tyrosine kinase in FLT3driven AML. Thus, we sought to examine the in vitro and in vivo anti-leukemic and biological activity of silvestrol in FLT3-ITD or FLT3-wt overexpressing AML cell lines and primary blasts.

\section{Methods \\ Reagents}

Silvestrol was kindly provided by Dr. A. Douglas Kinghorn. PKC412 was purchased from LC Laboratories (Woburn, MA, USA).

\section{Cell lines and primary blasts}

MV4-11 and THP-1 cells (ATCC, Manassas, VA) were cultured in RPMI 1640 medium supplemented with $10 \%$ calf serum. Blasts from AML patients were maintained in RPMI 1640 medium supplemented with $30 \%$ fetal bovine serum, $1 \%$ HEPES buffer, and 1× StemSpan CC100 (StemCell Technologies, Vancouver, BC, Canada) containing IL-3, IL-6, FLT3 ligand and SCF. All cells were incubated at $37^{\circ} \mathrm{C}$ with $5 \% \mathrm{CO}_{2}$. Patient AML blasts were obtained from apheresis blood samples collected from patients treated at the Ohio State University (OSU) and stored in the OSU Leukemia Tissue Bank. Informed consent to use cells for investigational studies was obtained from each patient under an OSU Institutional Review Board-approved protocol, according to the Declaration of Helsinki. Authenticating tests of these cell lines was done using monoclonal antibodies and FLT3 mutational analysis.

\section{Immunoblot analyses}

Cells were suspended $30 \mathrm{~min}$ in $1 \times$ lysis buffer $(20 \mathrm{mM}$ Hepes, $150 \mathrm{mM} \mathrm{NaCl}, 0.1 \% \mathrm{NP} 40$ ) containing protease inhibitor cocktail III (Calbiochem, Darmstadt, Germany) and lysate was recovered by centrifugation. Lysates were separated using 4-20\% SDS-PAGE and transferred to PVDF membrane (GE Healthcare, Piscataway, NJ). Membranes were blocked using $5 \%$ milk or BSA in $1 \times$ TBS with $0.1 \%$ Tween $20(1 \times \mathrm{TBS}-\mathrm{T})$ for 1 hour at room temperature with shaking, then incubated overnight at $4{ }^{\circ} \mathrm{C}$ in the following primary antibodies diluted in $1 \times$ TBS-T with 5\% milk or BSA: actin (Santa Cruz Biotechnology, Santa Cruz CA), FLT3 (Cell Signaling, Danvers, MA), phosphorylated and total STAT5 (Cell Signaling), P65 antibody (Billerica, MA). Membranes were washed using $1 \times$ TBS-T, incubated with HRP-conjugated secondary antibodies diluted in $1 \times$ TBS-T with $5 \%$ milk or BSA, washed, and developed using ECL Western Blotting Detection reagents (GE Heathcare).

\section{RNA immunoprecipitation (RIP), RNA extraction, Real- Time RT-PCR}

MV4-11 cells were treated with $50 \mathrm{nM}$ silvestrol for 3 hour, lysed (5 min) in $100 \mathrm{mM} \mathrm{KCl}, 5 \mathrm{mM} \mathrm{MgCl}, 10 \mathrm{mM}$ HEPES [pH 7.0], 0.5\% NP-40, $1 \mathrm{mM}$ dithiothreitol (DTT), 100 units/ml RNase OUT (Invitrogen), $400 \mathrm{mM}$ vanadylribonucleoside complex and protease inhibitors (Roche, 
Mannheim. Germany). Extracts were clarified and stored at $-80^{\circ} \mathrm{C}$. Anti-eIF4E antibody (cell signaling) and goat IgG (Sigma, St. Louis, MO) were incubated with protein sepharose A/agarose G-coupled beads overnight. Beads were subsequently washed four times with $50 \mathrm{mM}$ TRIS/ $\mathrm{HCl}$, $\mathrm{pH}$ 7.0, $150 \mathrm{mM} \mathrm{NaCl}, 1 \mathrm{mM} \mathrm{MgCl}_{2}$, and $0.05 \% \mathrm{NP}-40$, and twice after addition of $1 \mathrm{M}$ urea. Precipitates were digested with proteinase $\mathrm{K}\left(55^{\circ} \mathrm{C}\right)$, and eIF4E-associated mRNAs were isolated using Trizol reagent (Invitrogen, Grand Island, NY). cDNA was synthesized using SuperScript III reagents (Invitrogen) and the TaqMan MicroRNA Reverse Transcription Kit (Applied Biosystems, Foster City, CA) according to the manufacturer's instructions. Quantitative Real-Time RT-PCR for FLT3 and PU.1 genes and miR-155 and miR-34a expression was performed using commercially available TaqMan Gene Expression Assay primers and probes and the 7900HT Fast Real-Time PCR System (Applied Biosystems). The comparative cycle threshold $\left(\mathrm{C}_{\mathrm{T}}\right)$ method was used to determine the expression levels normalized by the internal control $18 S$ for gene expression.

\section{Clonogenic and viability analysis}

Methylcellulose clonogenic assays were carried out by plating $2 \times 10^{4}$ primary blasts in $0.9 \%$ MethoCult (Stem Cell Technologies). Colonies $(>100 \mathrm{~mm})$ from cell lines and primary cells were scored 14 days later. Growth inhibition assays were performed. Briefly, $5.0 \times 10^{4}$ cells were incubated in triplicate in a 96-well plate in the presence or absence of the different concentrations of silvestrol in a final volume of $100 \mu \mathrm{l}$ for 24,48 and 72 hours at $37^{\circ} \mathrm{C}$. Thereafter, $20 \mu \mathrm{l}$ of the CellTiter $96^{\circledR} \mathrm{AQ}_{\text {ueous }}$ One Solution Reagent which contains tetrazolium compound [3-(4,5-dimethyl-2-yl)-5-(3-carboxymethoxyphenyl)2-(4-sulfophenyl)-2H-tetrazolium, inner salt; MTS] and an electron coupling reagent (phenazine ethosulfate; PES) (Promega, Madison WI) was added to each well. After 4 hours incubation at $37^{\circ} \mathrm{C}$, the optical density at $490 \mathrm{~nm}$ was measured. Cell viability was calculated with respect to the control samples. At least three independent experiments were performed.

\section{Flow cytometry}

For FLT3 detection, cells $\left(5 \times 10^{5}\right)$ were washed with phosphate-buffered saline (PBS) and resuspended in $50 \mu \mathrm{l}$ binding buffer containing $5 \mu \mathrm{L}$ FLT3 antibody (BD Biosciences, Billerica, MA). After 15 min incubation, cells were washed with PBS, resuspended in $400 \mu \mathrm{L}$ flow buffer and analyzed on a FACSCalibur cytometer (BD Biosciences). To assess apoptosis, AML cells were incubated with 10, 30 and $50 \mathrm{nM}$ silvestrol for 24 hours. Cells $\left(5 \times 10^{5}\right)$ were then washed with PBS and resuspended in $50 \mu \mathrm{l}$ binding buffer containing $2 \mu \mathrm{L}$ of annexin V-FITC stock (BioWhittaker, Inc, Walkersville, $\mathrm{MD}$ ) and $5 \mu \mathrm{L}$ propidium iodide (PI) (BD
Biosciences). After $20 \mathrm{~min}$ incubation, fluorescence was quantified by flow cytometry on a FACSCalibur instrument.

\section{MV4-11 xenograft murine model}

This model was developed recently in our laboratory and described previously [25]. Briefly, $4 \sim 6$ week-old non-obese diabetic severe combined immunodeficient gamma (NSG) mice (NOD.Cg-Prkdcscid Il2rgtm1Wjl/SzJ, The Jackson Laboratory, Bar Harbor, ME) were intravenously (i.v) injected via tail vein with $2 \times 10^{7} \mathrm{MV} 4-11$ cells. Two months later, the spleen mononuclear cells (MNCs) were isolated from MV4-11-injected mice ( $1^{\text {st }}$-adapted MV4-11 cells in NSG mice). The adapted spleen MNCs were injected into a new cohort of NSG mice via tail vein. The loading dose of cells was reduced to $50 \%$ in this second transplantation. About a month later, the spleen MNC were isolated and a $3^{\text {rd }}$ transplantation was performed using $0.5 \times 10^{7}$ cells/mouse spleen MNC from $2^{\text {nd }}$ adapted NSG mice. The sequential transplants were performed using $0.5 \times 10^{6}$ cells/mouse spleen MNC from $3^{\text {rd }}$ adapted NSG mice. This provides a more aggressive and fast onset of AML-like disease, thereby allows for rapid read-out of the experiment. Indeed, we observed development of leukemia at only two weeks from injection and a median survival of approximately 4 weeks after engraftment of the adapted MV4-11 cells from the $3^{\text {rd }}$ transplant. The complete blood count and FACS analysis of CD45 and FLT3 expression and cytospin were examined weekly to monitor the progression of disease. All the experiments were conducted in accordance with the institutional guidelines for animal care and use.

Spleen cells $\left(0.5 \times 10^{6}\right)$ from MV4-11 transplanted NSG mice were intravenously (iv) injected into NSG mice via tail vein, and divided into groups for vehicle (hydroxypropyl beta-cyclodextrin in $30 \%$ sterile water; $\mathrm{N}=6$ ) or silvestrol (1.5 $\mathrm{mg} / \mathrm{kg}$ in vehicle; $\mathrm{N}=10$ ) treatment. One control mouse (no leukemia/no treatment) was also included. Two to three weeks after engraftment, white blood count (WBC) and FLT3 expression by flow cytometry were assessed to confirm transplantation. Treatments with silvestrol or vehicle were initiated 21 days after engraftment (based on disease signs documented by WBC count and FLT3 expression). Administration was by intraperitoneal injection every 48 hours for up to three weeks or until euthanasia criteria were met. Expected median survival of untreated animals in this model is 28 days. Mice were weighed daily and checked for signs of dehydration, discomfort or toxicity. On day of administration, doses were recalculated for each animal after weighing to maintain $1.5 \mathrm{mg} / \mathrm{kg}$. For the pharmacodynamic study, 6 mice were used ( 3 per group, vehicle and silvestrol). These mice were given 3 doses of either vehicle or silvestrol; and 48 hours following the third dose, spleens were isolated and mononuclear cells obtained for immunoblotting assay. For pathological examination, tissue sections from the liver, spleen 


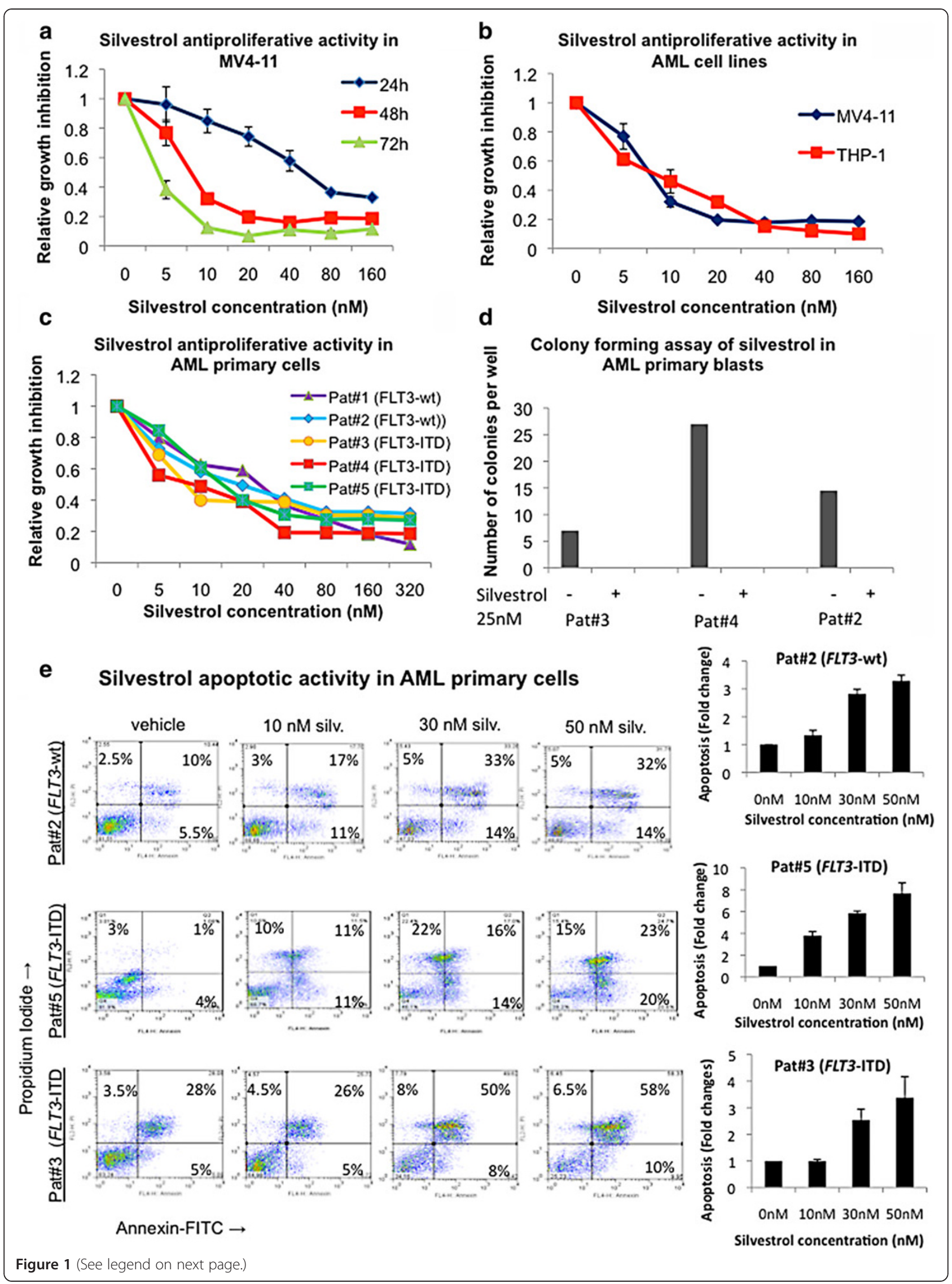


(See figure on previous page.)

Figure 1 Antileukemic activity of silvestrol in vitro: (a) MV4-11 cells were incubated with 5 to $160 \mathrm{nM}$ silvestrol. Cell viability was evaluated by a MTS assay at 24, 48 and 72 hours. (b) AML cell lines were incubated with 5 to $160 \mathrm{nM}$ silvestrol, and viability was evaluated by a MTS assay 48 hours later. (c) AML primary cells unmutated FLT3 or with FLT3-ITD were incubated with 5 to $320 \mathrm{nM}$ silvestrol. Cell viability was evaluated by MTS assay 48 hours following treatment. (d) Colony forming ability in primary blasts from FLT3-ITD positive and negative AML patients treated with $25 \mathrm{nM}$ of silvestrol and scored 14 days later. (e) Primary blasts from FLT3-ITD positive and negative AML patients treated with 10, 30 and 50 nM of silvestrol for 48 hours and analyzed by annexin/PI flow cytometry. Values are presented as mean \pm SEM.

and bone marrow sternum were fixed on formalin, embedded in paraffin blocks, and H\&E stained.

\section{Wright-Giemsa staining}

Morphological signs of apoptosis were detected by Wright-Giemsa staining. Smears of control and treated cells were stained with Wright-Giemsa solution for $25 \mathrm{~min}$, rinsed with distilled water and air dried. Cell morphology was studied by light microscopy.

\section{Results}

Silvestrol antileukemia activity in AML cells

The antileukemia activity of silvestrol was first tested in AML cell lines. MV4-11 cells are FLT3-ITD positive, whereas THP-1 cells are negative for FLT3-ITD but express robust levels of FLT3-wt. Silvestrol impacted leukemia growth (measured by MTS) in a dose- (5 to $160 \mathrm{nM}$ ) and time-dependent manner (Figure 1a). At 48 hours, $\mathrm{IC}_{50}$ values (concentration required to inhibit growth to $50 \%$ of control) were 2.7 and $3.8 \mathrm{nM}$ in MV4-11 and THP-1 cells, respectively (Figure $1 \mathrm{~b}$ and Table 1 ). Primary blasts from three AML patients with FLT3-ITD and two AML patients with FLT3-wt were treated with 5 to $320 \mathrm{nM}$ silvestrol. A dose-dependent decrease in proliferation was observed, with $\mathrm{IC}_{50}$ values at 48 hours of $3.7,4.9$, and $6.4 \mathrm{nM}$ for the blasts from the FLT3-ITD patients ( $\mathrm{n}=3), 16.9$ and $6.6 \mathrm{nM}$ for the blasts from the FLT3-wt patients $(\mathrm{n}=2$; Figure $1 \mathrm{c}$ and Table 1). We also performed a colony forming assay of silvestrol in primary samples from three of the five patients, including two of the FLT3-ITD positive cases. We observed no colony formation for any of the tested samples when blasts were treated with $25 \mathrm{nM}$ of silvestrol (Figure 1d).

Table 1 Calculated IC 50 values for AML cell lines and primary blasts at $48 \mathrm{~h}$

\begin{tabular}{|c|c|c|}
\hline Cell line & FLT3 status & $\mathrm{IC}_{50}(95 \%$ Confidence intervals $)$ \\
\hline MV4-11 & FLT3-ITD & $2.65 \mathrm{nM}(1.49$ to 4.72$)$ \\
\hline THP-1 & FLT3-wt & $3.81 \mathrm{nM}$ (2.46 to 5.09$)$ \\
\hline \multicolumn{3}{|c|}{ Primary blasts } \\
\hline Pat \#1 & FLT3-wt & $16.9 \mathrm{nM}$ (13.6 to 21.1$)$ \\
\hline Pat \#2 & FLT3-wt & $6.61 \mathrm{nM}(5.67$ to 7.70$)$ \\
\hline Pat \#3 & FLT3-ITD & $3.65 \mathrm{nM}$ (2.21 to 6.04) \\
\hline Pat \#4 & FLT3-ITD & $4.89 \mathrm{nM}(3.90$ to 6.12$)$ \\
\hline Pat \#5 & FLT3-ITD & $6.41 \mathrm{nM}$ (4.07 to 10.1$)$ \\
\hline
\end{tabular}

To determine whether exposure to silvestrol resulted in apoptosis, we utilized annexin and PI staining of cells treated with 10-50 nM silvestrol for 48 hours. A dosedependent increase in apoptosis was observed in silvestrol treated compared with vehicle-treated primary blasts from FLT3-ITD $(\mathrm{n}=3)$ as well as FLT3-wt $(\mathrm{n}=2)$ AML patients (Figure 1e). In AML primary cells, silvestrol induced 1 to 7.5 fold increase in apoptosis in both FLT3-wt and FLT3-ITD blasts ( $\mathrm{P}=0.0001$ for every tested case) treated with 10,30 and $50 \mathrm{nM}$ of silvestrol compared with vehicle treated controls.

\section{Silvestrol downregulates FLT3 expression through inhibition of FLT3 translation initiation}

Silvestrol interferes with assembly of the eIF4F translation complex by promoting an aberrant interaction between capped mRNA and eIF4A, thus blocking protein synthesis at the initiation step $[21,24]$. This inhibition of protein synthesis results in a preferential depletion of proteins with short half-lives to which leukemia and cancer cells may be addicted [22,24]. However, whether silvestrol also inhibits FLT3 initiation of translation resulting in inhibition of FLT3 protein synthesis has not been reported. Thus, using an RNA immunoprecipitation assay, we tested this possibility.

Because of the difficulty immunoprecipitating eIF4A protein for the RNA immunoprecipitation assay using commercially available antibodies, we utilized an antibody against eIF4E, a subunit of the initiation of translation complex that binds the mRNA cap structure. To avoid the interference due to cell death usually observed with more prolonged drug exposure and at the same time to ensure adequate pharmacologic activity, cells were exposed to silvestrol at concentrations that were higher than the calculated in vitro $\mathrm{IC}_{50}$ but that were also achievable in vivo, and harvested at 24 hours or earlier time points [26]. MV4-11 cells were treated with $50 \mathrm{nM}$ silvestrol for 3 hours and eIF4E was immunoprecipitated in three different experiments. Associated RNA was then assessed for depletion of FLT3 RNA by quantitative RT-PCR. While no change in FLT3 mRNA levels was observed in total RNA from MV4-11 cells treated with silvestrol compared with vehicle-treated cells, a five-fold depletion of FLT3 mRNA was detected in eIF4E immunoprecipitates from silvestroltreated cells compared with vehicle-treated cells at 3 hours 


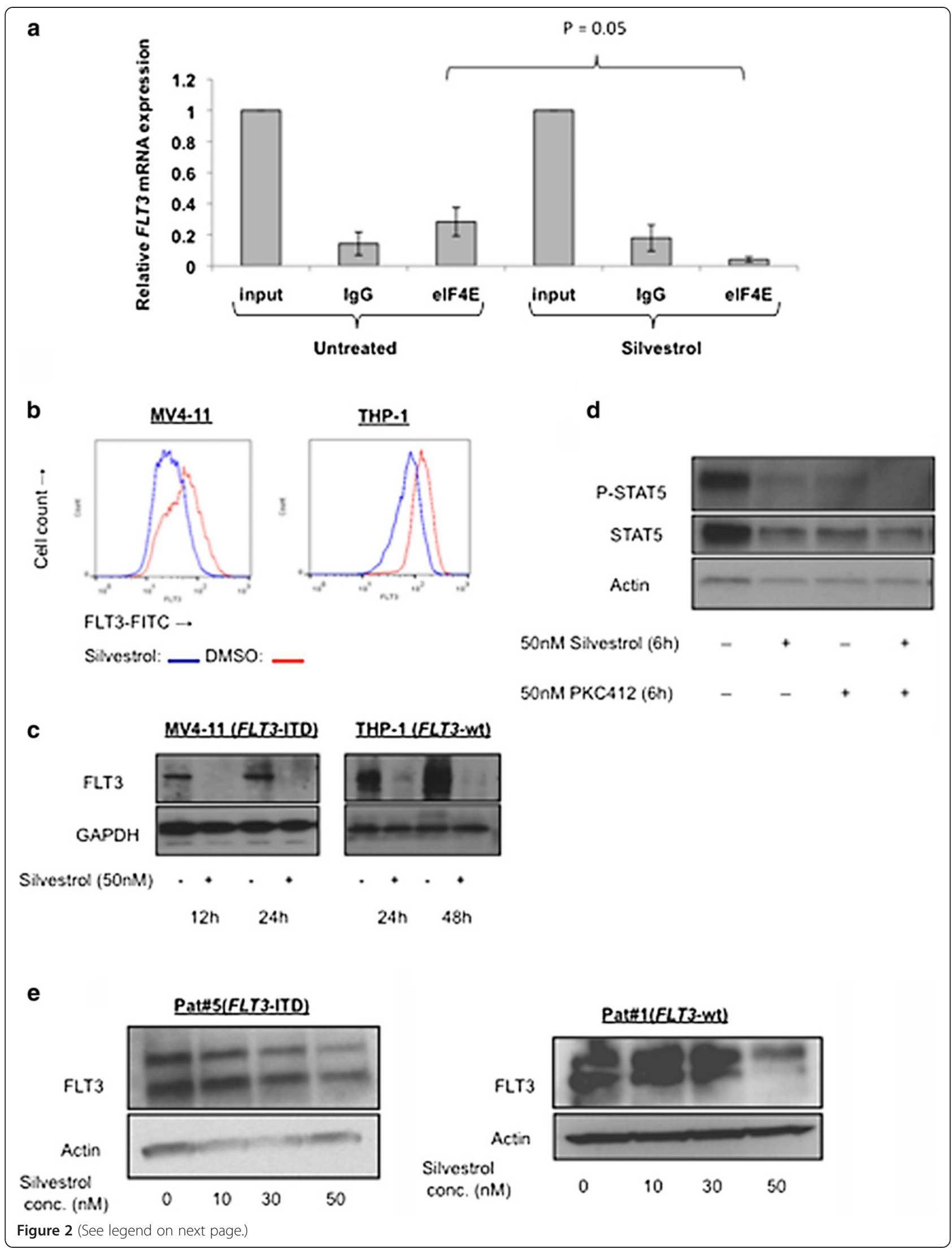


(See figure on previous page.)

Figure 2 Silvestrol down-regulates FLT3: (a) FLT3 mRNA expression in elF4E immunoprecipitates from 50 nM silvestrol treated MV4-11 cells compared with that from untreated cells. Values are presented as mean \pm SEM. (b) Expression of FLT3 examined by flow cytometry in MV4-11 and THP-1 cells after 24 hours exposure to $50 \mathrm{nM}$ silvestrol. Blue = silvestrol-treated samples; Red = vehicle-treated control. (c) AML cells treated with 50 nM silvestrol and examined for FLT3 protein expression by immunoblotting. (d) MV4-11 cells treated with silvestrol or PKC412 (50 nM each) for 6 hours, and assessed for STAT5 phosphorylation by immunoblotting. (e) Primary AML cells incubated with increasing concentrations of silvestrol for 24 hours, and assessed for FLT3 protein expression by immunoblotting.

(Figure 2a). This resulted in $54 \%$ and $46 \%$ reduction in FLT3 receptor expression (by flow cytometry) (Figure 2b) and $92 \%$ and $84 \%$ reduction in FLT3-ITD or FLT3-wt protein levels (by western blot) respectively in MV4-11 and THP-1 cells, exposed to $50 \mathrm{nM}$ silvestrol for 24 hours, compared with vehicle-treated controls (Figure 2c). Since total FLT3 protein levels were almost undetectable following silvestrol treatment, phosphorylated FLT3 was expected with be depleted as well. Therefore, TK activity was determined by measuring phosphorylation of the FLT3 target protein STAT5 in MV4-11 cells, which was found decreased following silvestrol treatment (Figure 2d). Similarly, down-regulation of FLT3 protein was observed in silvestrol-treated primary blasts (FLT3-wt and FLT3ITD) (Figure 2e).

\section{Silvestrol downregulates miR-155 expression in FLT3-ITD positive AML}

MicroRNAs are short, non-coding RNA that disrupt translation of mRNA targets, thereby resulting in down regulation of the mRNA corresponding encoded proteins. miR-155 has a known oncogenic activity in hematologic malignancies $[27,28]$. Sustained expression of this miR in hematopoietic stem cells causes a myeloproliferative disorder [29]. We and others reported that miR-155 is up-regulated in FLT3-ITD positive AML compared with FLT3-wt AML, although whether this microRNA directly contributes to the leukemogeneic activity of FLT3-ITD is unknown $[4,30,31]$. Having shown that silvestrol downregulated FLT3-ITD protein, next we tested whether silvestrol also altered the expression of miR-155 that appears co-regulated with FLT3. Thus, miR-155 expression was measured in MV4-11 cells treated with $50 \mathrm{nM}$ of silvestrol by qRT-PCR. We found approximately a $60 \%$ decrease in $m i R-155$ expression in silvestrol treated compared with untreated cells $(P=0.05)$, while no significant change was observed in the expression of an unrelated miRs (i.e., miR-34) (Figure 3a, b and c). In order to examine the effect of silvestrol on miR-155 function, we treated MV4-11 cells with $50 \mathrm{nM}$ silvestrol and assessed the mRNA expression of the miR-155 target gene PU.1 [32]. Twenty-four hours following treatment with silvestrol, PU.1 expression showed about 2 folds increase in the mRNA expression level compared with untreated MV4-11 ( $\mathrm{P}=0.04) \quad$ (Figure 3d). Similar results were obtained in FLT3-ITD positive primary blasts; these cells exhibited $60 \%$ decrease in miR-155 expression $(\mathrm{P}<0.01)$ and a 1.6-fold increase in PU.1 expression ( $\mathrm{P}<0.01), 24$ hours following treatment with $50 \mathrm{nM}$ of silvestrol compared with untreated cells (Figure $3 e$ and f).

The mechanisms through which constitutively activated FLT3 associates with increased miR-155 expression are unknown. However, $m i R-155$ has been reported to be a target of NF- $\mathrm{kB}$, which is also potentially activated in AML blasts with constitutively activated FLT3 [33,34]. Additionally, Gerlof et al. reported that FLT3-ITD induces the oncogenic $m i R-155$ via STAT5 and NF-kB (p65) [35]. Given that silvestrol belongs to the rocaglate derivatives, which have been reported to inhibit the activity of NF-kB $[18,36]$, we then verified the effect of silvestrol on NF-kB protein levels. When we treated MV4-11 and THP-1 cells with $50 \mathrm{nM}$ of silvestrol for 24 hours, we observed decrease in NF- $\mathrm{KB}$ (P65) protein expression in silvestrol-treated cells compared with vehicle-treated cells (Figure $3 \mathrm{~g}$ ). This suggests that silvestrol may induce miR-155 downregulation likely through direct inhibition of NF- $\mathrm{kB}$ (FLT3-ITD-negative THP-1 cells), and indirect inhibition of $N F-\kappa B$ via FLT3-ITD-dependent mechanisms (FLT3-ITD-positive MV4-11 cells). Nevertheless, the compound effectively targets both the microRNA and the mutant protein that may concurrently contribute to the aggressiveness of FLT3-ITD AML.

\section{Activity of silvestrol in FLT3-ITD positive leukemia grafts}

A MV4-11 leukemia graft murine model was employed to investigate the in vivo efficacy of silvestrol in AML. NSG mice were subjected to secondary transplant with MV4-11 cells harvested from the spleen of previous MV4-11 engrafted mice that developed an aggressive AML-like disease. Twenty-one days post-engraftment, mice were treated intraperitoneally with vehicle (Group 1) or $1.5 \mathrm{mg} / \mathrm{kg}$ silvestrol (Group 2) every other day for 3 weeks. The silvestrol dose and schedule used here were previously reported for lymphoid leukemia models $[22,37]$. Forty-eight hours following the first two doses, blood samples with circulating MV4-11 cells were taken from 3 mice from each group, and FLT3 expression was assessed by flow cytometry. A two- and three-folds increase in FLT3 expression was observed in vehicletreated mice 48 hours after the first $(\mathrm{P}=0.07)$ and second $(P=0.024)$ treatment doses compared with 


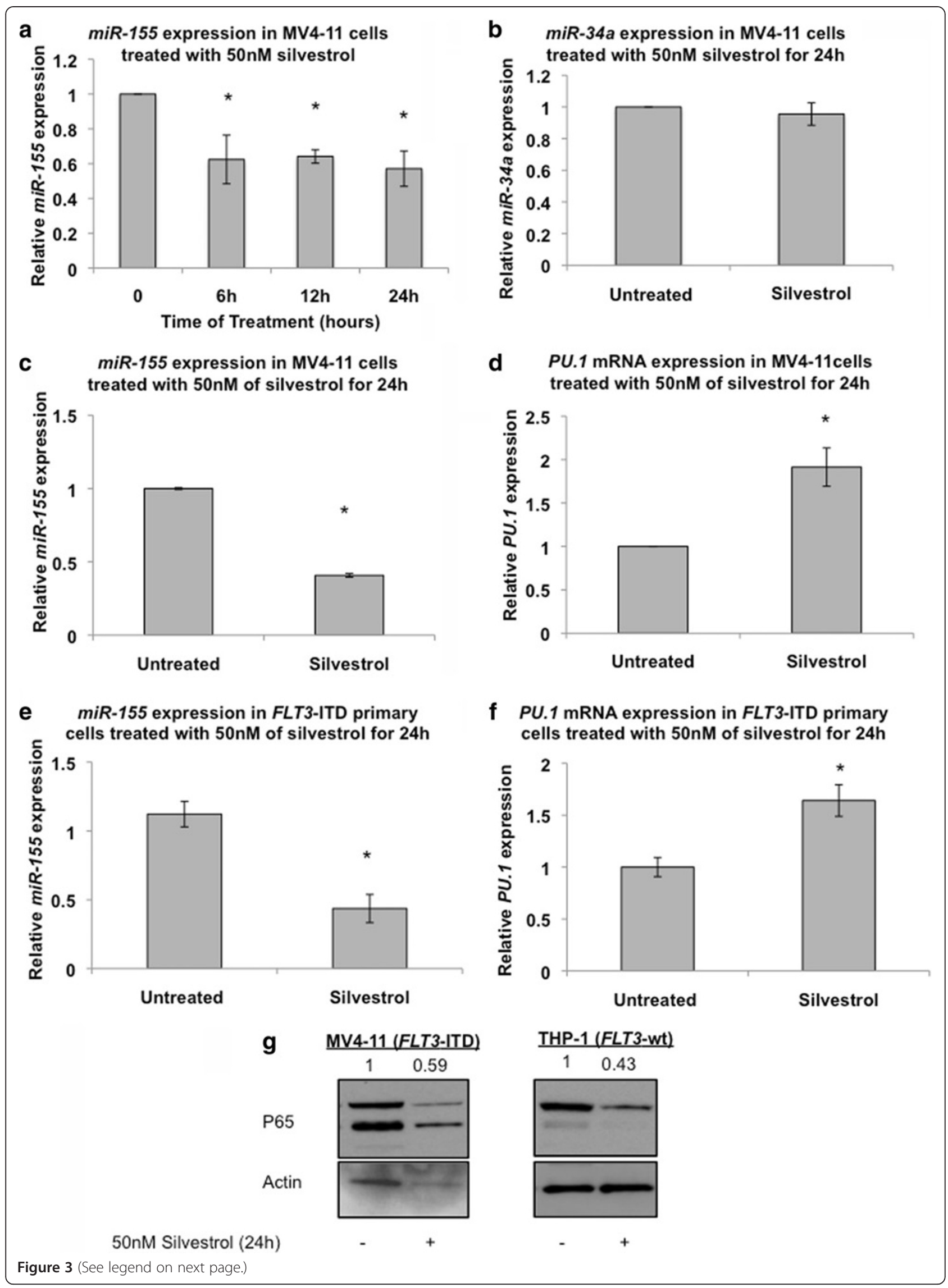


Figure 3 Silvestrol down-regulates miR-155 and upregulates miR-155 target PU.1: (a) MV4-11 cells were treated with $50 \mathrm{nM}$ of silvestrol and miR-155 expression was measured and normalized to U44 expression at 6, 12 and 24 hours following silvestrol treatment.

(b) MV4-11 cells were treated with $50 \mathrm{nM}$ of silvestrol for 24 hours, and miR-34a expression was measured thereafter. (c,d) MV4-11 cells were treated with $50 \mathrm{nM}$ of silvestrol for 24 hours, and miR-155 (c) and PU.1 expression (d) levels were measured thereafter. (e,f) FLT3-ITD positive primary cells were treated with $50 \mathrm{nM}$ of silvestrol for 24 hours, and miR-155 expression (e) and PU.1 expression (f) levels were measured thereafter. (g) MV4-11 and THP-1 cells were treated with $50 \mathrm{nM}$ of silvestrol for 24 hours and assessed for P65 protein expression by immunoblotting. Values are presented as mean \pm SEM.

pretreatment baseline, while no significant change was found in the silvestrol treatment group (Figure 4a). After 3 doses (day 6 of treatment), spleens from three mice from each group were examined. Spleens from silvestrol treated mice were $60 \%$ smaller $(P=0.016)$ (Figure $4 \mathrm{~b})$, and showed an $80 \%$ reduction in FLT3 protein $(\mathrm{P}=0.002)$ compared with vehicle-treated controls (Figure 4c). Cytospins of bone marrow cells and histopathology of bone marrow (sternum), spleen, and liver sections from MV4-11-engrafted mice treated with vehicle showed extensive infiltration of blast cells. In contrast, cytospins and histopathology from silvestrol-treated leukemic mice were similar to those of the age-matched control mice (Figure 4d, e). Silvestroltreated leukemic mice $(n=10)$ survived significantly longer than the vehicle-treated controls $(n=6)$ (median survival: 63 days from engraftment vs. 29 days, respectively; $\mathrm{P}<0.0001$ ). All mice in the vehicle group died by day 31 from engraftment (day 11 from treatment start), while 50\% of silvestrol-treated mice were still alive on day 74 from engraftment (day 54 from treatment start) (Figure 4f). Of the silvestrol-treated mice, $30 \%$ were still alive at 6 months from experiment start day. When sacrificed, these survived mice showed no signs of leukemia.

\section{Discussion}

The natural product silvestrol has been shown to inhibit translation initiation by modulating the interaction of capped mRNA with the RNA helicase eIF4A [24]. Protooncogenes such as CCND1, MCL1, and MYC tend to encode proteins with short half-lives, and are therefore more dependent on active translation to maintain protein levels that support malignant cell growth and survival. Such factors and in turn cancer cells addicted to them, are thus expected to be more sensitive to translation inhibition by silvestrol, as was recently reported [21-23,37]. To our knowledge, the effect of silvestrol on FLT3 expression has not been previously reported. Here we report that silvestrol also inhibits FLT3 mRNA translation thereby causing depletion of the encoded oncoprotein, inhibition of the protein's aberrant tyrosine kinase activity. Silvestrol caused growth arrest and apoptosis in AML cell lines and primary blasts treated at nanomolar concentrations. These results therefore extend the list of the oncoproteins targeted by silvestrol and support the antileukemia activity of this compound.
Most importantly, we showed a remarkable in vivo activity of silvestrol in a FLT3-ITD leukemia engraftment model. Mice engrafted with adapted MV4-11 cells developed leukemia and had a median survival of only 4 weeks. Treatment with silvestrol had no obvious toxicity and lowered the FLT3 expression to undetectable levels after administration of only three doses. Silvestrol treatment significantly prolonged survival and even cured approximately $30 \%$ of the animals, further reinforcing the concept that pursuing suppression of the FLT3-ITD protein expression may be a valid therapeutic approach in FLT3-driven AML. Recently, there has been an increased interest in utilizing small molecule kinase inhibitors to target aberrant TK activity of FLT3 mutants that contribute to leukemia growth and poor outcome in AML patients [38]. Unfortunately, the lack of selectivity, inadequate pharmacokinetics, and early onset of resistance resulted in relatively disappointing outcomes with these agents $[39,40]$. Nevertheless, FLT3 down-regulation via siRNA has been shown to result in growth inhibition and apoptosis in FLT3-ITD-positive AML cells $[33,41]$. This implicates that interfering not only with aberrant activity of this kinase but also with FLT3 expression might be a useful therapeutic strategy in AML. Thus, drugs like silvestrol, that have the ability to decrease the expression of FLT3 may be clinically useful in this distinct subset of AML addicted to the FLT3 aberrant TK activity.

Although activity of silvestrol on the FLT3 expression was impressive, it is likely that silvestrol as a natural product and an inhibitor of eIF4A has the ability to alter the expression and activity of several other targets that may contribute to the impairment of leukemia growth. Nevertheless, the antileukemia activity of this natural product may result favorable for those FLT3-driven molecular subsets of AML that are resistant to chemotherapy and/or enzymatic kinase inhibitors. To this end, we not only showed silvestrol-related FLT3 suppression, but also downregulation of $m i R-155$, an oncomiR whose expression is likely regulated by NF- $\mathrm{kB}$ often found constitutively activated in FLT3-driven AML [42,43]. This microRNA has been shown to be upregulated in FLT3-ITD positive AML, and is thought to contribute to leukemia growth and aggressiveness in these molecular subsets of AML through downregulation of several targets including PU.1 $[4,31,44]$. Indeed, we showed that 


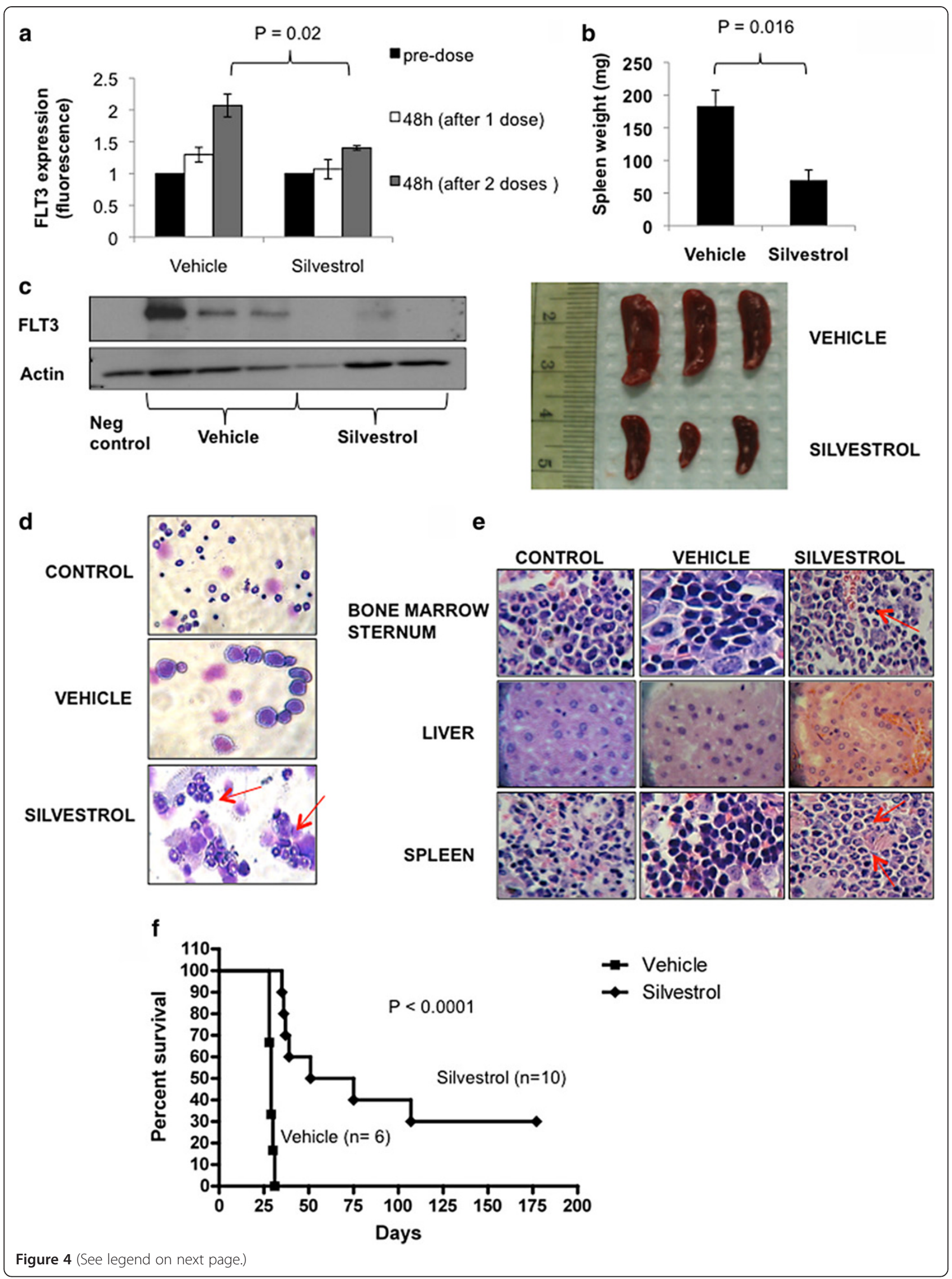


(See figure on previous page.)

Figure 4 In vivo antileukemic activity of silvestrol in FLT3-ITD positive MV4-11 xenograft leukemia mouse model: (a) FLT3 expression by flow cytometry evaluated 48 hours after $1^{\text {st }}$ and $2^{\text {nd }}$ doses. (b) Spleen size after 3 silvestrol doses (day 6 of treatment) (c) Immunoblot of FLT3 protein expression in spleens from silvestrol-treated mice and vehicle-treated controls. (d) Cytospins of bone marrow cells and (e) histopathology of bone marrow (sternum), spleen, and liver from the silvestrol-treated and vehicle-treated leukemic mice and age-matched (non-leukemic) control mice showing the infiltration of leukemic blasts in the vehicle treated and signs of differentiation in the silvestrol treated mice (see red pointing arrows). Stain: H\&E; magnifications, 400x. (f) Survival analysis of silvestrol-treated leukemic mice $(\mathrm{N}=10)$ compared with the vehicletreated controls $(\mathrm{N}=6)$. Values are presented as mean \pm SEM.

silvestrol increased PU.1 expression, which has been previously reported to inversely correlate with FLT3 levels [45]. Thus, the dual activity of silvestrol on FLT3 and miR-155 expression suggests that this compound may represent a potentially valuable therapeutic approach to this high-risk AML subset.

\section{Conclusions}

We showed that silvestrol is a compound with a potent anti-leukemia activity in FLT3-driven AML. These results thereby provide a novel therapeutic strategy in FLT3-driven AML by a novel mechanism that is not based on the disruption of the aberrant tyrosine kinase activity through enzymatic TK inhibition, but rather it is effective via translation inhibition of FLT3 mRNA. Given these and other previously published findings [22,37], silvestrol is now under preclinical development in the National Cancer Institute's NExT Program for a rapid translation into the clinic.

\section{Competing interests}

The authors declare that they have no competing interests.

\section{Authors' contributions \\ HA, DML, MRG and GM designed experiments, critically evaluated the work and took overall supervision in the preparation of manuscript; HA and GM wrote the manuscript; HA performed experiments; RS performed in vivo experiments; JGH performed RNA immunoprecipitation; LP and ADK performed silvestrol extraction and preparation for in vitro and in vivo studies; JJO, CJH, LP, ADK, MAC, DP, JCB, RG provided technical insight and critically reviewed the paper; All authors read and approved the final manuscript.}

\section{Acknowledgment}

We thank Dr. Shujun Liu and Sebastian Schwind for helpful discussions, Xia Pang for the technical support.

\section{Grant support}

This work was supported by the U.S. National Cancer Institute [P01CA125066 to ADK, SPORE P50-CA140158 to JCB, and The Ohio State University Comprehensive Cancer Center Core Grant].

\footnotetext{
Author details

'Division of Hematology, Department of Medicine, The Ohio State University, Columbus, OH, USA. ²Department of Molecular Virology, Immunology and Cancer Genetics, The Ohio State University, Columbus, OH, USA. ${ }^{3}$ Division of Medicinal Chemistry and Pharmacognosy, College of Pharmacy, The Ohio State University, Columbus, OH, USA. ${ }^{4}$ Comprehensive Cancer Center, The Ohio State University, Columbus, OH, USA. ${ }^{5}$ The Ohio State University Comprehensive Cancer Center, Biomedical Research Tower 460 W. 12th Ave, Columbus, OH 43210, USA. ${ }^{6} 395$ West Twelfth Avenue, Rm. 392 North Doan Office Tower, Columbus, $\mathrm{OH}$ 43210, USA.
}

\section{References}

1. Estey E, Dohner H: Acute myeloid leukaemia. Lancet 2006, 368(9550):1894-1907.

2. Takahashi S: Downstream molecular pathways of FLT3 in the pathogenesis of acute myeloid leukemia: biology and therapeutic implications. J Hematol Oncol 2011, 4:13.

3. Meshinchi S, Appelbaum FR: Structural and functional alterations of FLT3 in acute myeloid leukemia. Clin Cancer Res 2009, 15(13):4263-4269.

4. Whitman SP, Maharry K, Radmacher MD, Becker H, Mrozek K, Margeson D, Holland KB, Wu YZ, Schwind S, Metzeler KH, Wen J, Baer MR, Powell BL, Carter TH, Kolitz JE, Wetzler M, Moore JO, Stone RM, Carroll AJ, Larson RA, Caligiuri MA, Marcucci G, Bloomfield CD: FLT3 internal tandem duplication associates with adverse outcome and gene- and microRNA-expression signatures in patients 60 years of age or older with primary cytogenetically normal acute myeloid leukemia: a Cancer and Leukemia Group B study. Blood 2010, 116(18):3622-3626.

5. Beran M, Luthra R, Kantarjian H, Estey E: FLT3 mutation and response to intensive chemotherapy in young adult and elderly patients with normal karyotype. Leuk Res 2004, 28(6):547-550.

6. Krause DS, Van Etten RA: Tyrosine kinases as targets for cancer therapy. N Engl J Med 2005, 353(2):172-187.

7. Weisberg E, Sattler M, Ray A, Griffin JD: Drug resistance in mutant FLT3positive AML. Oncogene 2010, 29(37):5120-5134.

8. Bang SM, Ahn JY, Park J, Park SH, Park J, Cho EK, Shin DB, Lee JH, Yoo SJ, Jeon IS, Kim YK, Kim HJ, Kim HN, Lee IK, Kang HJ, Shin HY, Ahn HS: Low frequency and variability of FLT3 mutations in Korean patients with acute myeloid leukemia. J Korean Med Sci 2008, 23(5):833-837.

9. Ozeki K, Kiyoi H, Hirose Y, Iwai M, Ninomiya M, Kodera Y, Miyawaki S, Kuriyama K, Shimazaki C, Akiyama H, Nishimura M, Motoji T, Shinagawa K, Takeshita A, Ueda R, Ohno R, Emi N, Naoe T: Biologic and clinical significance of the FLT3 transcript level in acute myeloid leukemia. Blood 2004, 103(5):1901-1908.

10. Zheng R, Levis M, Piloto O, Brown P, Baldwin BR, Gorin NC, Beran M, Zhu Z, Ludwig D, Hicklin D, Witte L, Li Y, Small D: FLT3 ligand causes autocrine signaling in acute myeloid leukemia cells. Blood 2004, 103(1):267-274.

11. Smith CC, Wang Q, Chin CS, Salerno S, Damon LE, Levis MJ, Perl AE, Travers KJ, Wang S, Hunt JP, Zarrinkar PP, Schadt EE, Kasarskis A, Kuriyan J, Shah NP: Validation of ITD mutations in FLT3 as a therapeutic target in human acute myeloid leukaemia. Nature 2012, 485(7397):260-263.

12. Guo $Y$, Chen $Y, X u X, F u X$, Zhao ZJ: SU11652 Inhibits tyrosine kinase activity of FLT3 and growth of MV-4-11 cells. J Hematol Oncol 2012, 5:72.

13. Kindler T, Lipka DB, Fischer T: FLT3 as a therapeutic target in AML: still challenging after all these years. Blood 2010, 116(24):5089-5102.

14. Pratz KW, Sato T, Murphy KM, Stine A, Rajkhowa T, Levis M: FLT3-mutant allelic burden and clinical status are predictive of response to FLT3 inhibitors in AML. Blood 2010, 115(7):1425-1432.

15. Pratz KW, Cortes J, Roboz GJ, Rao N, Arowojolu O, Stine A, Shiotsu Y, Shudo A, Akinaga S, Small D, Karp JE, Levis M: A pharmacodynamic study of the FLT3 inhibitor KW-2449 yields insight into the basis for clinical response. Blood 2009, 113(17):3938-3946.

16. Hwang BY, Su BN, Chai H, Mi Q, Kardono LB, Afriastini JJ, Riswan S, Santarsiero BD, Mesecar AD, Wild R, Fairchild CR, Vite GD, Rose WC, Farnsworth NR, Cordell GA, Pezzuto JM, Swanson SM, Kinghorn AD: Silvestrol and episilvestrol, potential anticancer rocaglate derivatives from Aglaia silvestris. J Org Chem 2004, 69(10):3350-3358.

17. Kinghorn $A D$, Pan L, Fletcher $J N$, Chai $H$ : The relevance of higher plants in lead compound discovery programs. J Nat Prod 2011, 74(6):1539-1555.

18. Kim S, Hwang BY, Su BN, Chai H, Mi Q, Kinghorn AD, Wild R, Swanson SM: Silvestrol, a potential anticancer rocaglate derivative from Aglaia foveolata, induces apoptosis in LNCaP cells through the mitochondrial/ 
apoptosome pathway without activation of executioner caspase- 3 or -7 . Anticancer Res 2007, 27(4B):2175-2183.

19. Mi Q, Kim S, Hwang BY, Su BN, Chai H, Arbieva ZH, Kinghorn AD, Swanson SM: Silvestrol regulates $\mathrm{G} 2 / \mathrm{M}$ checkpoint genes independent of p53 activity. Anticancer Res 2006, 26(5A):3349-3356.

20. Gerard B, Cencic R, Pelletier J, Porco JA Jr: Enantioselective synthesis of the complex rocaglate (-)-silvestrol. Angew Chem Int Ed Engl 2007, 46(41):7831-7834.

21. Bordeleau ME, Robert F, Gerard B, Lindqvist L, Chen SM, Wendel HG, Brem B, Greger H, Lowe SW, Porco JA Jr, Pelletier J: Therapeutic suppression of translation initiation modulates chemosensitivity in a mouse lymphoma model. J Clin Invest 2008, 118(7):2651-2660.

22. Lucas DM, Edwards RB, Lozanski G, West DA, Shin JD, Vargo MA, Davis ME, Rozewski DM, Johnson AJ, Su BN, Goettl VM, Heerema NA, Lin TS, Lehman A, Zhang X, Jarjoura D, Newman DJ, Byrd JC, Kinghorn AD, Grever MR: The novel plant-derived agent silvestrol has B-cell selective activity in chronic lymphocytic leukemia and acute lymphoblastic leukemia in vitro and in vivo. Blood 2009, 113(19):4656-4666.

23. Cencic R, Carrier M, Trnkus A, Porco JA Jr, Minden M, Pelletier J: Synergistic effect of inhibiting translation initiation in combination with cytotoxic agents in acute myelogenous leukemia cells. Leuk Res 2010, 34(4):535-541.

24. Cencic R, Carrier M, Galicia-Vázquez G, Bordeleau ME, Sukarieh R, Bourdeau A, Brem B, Teodoro JG, Greger H, Tremblay ML, Porco JA Jr, Pelletier J: Antitumor activity and mechanism of action of the cyclopenta[b] benzofuran, silvestrol. PLoS One 2009, 4(4):e5223.

25. Ranganathan P, Yu X, Na C, Santhanam R, Shacham S, Kauffman M, Walker A, Klisovic R, Blum W, Caligiuri M, Croce CM, Marcucci G, Garzon B: Preclinical activity of a novel CRM1 inhibitor in acute myeloid leukemia. Blood 2012, 120(9):1765-1773.

26. Saradhi UV, Gupta SV, Chiu M, Wang J, Ling Y, Liu Z, Newman DJ, Covey JM, Kinghorn AD, Marcucci G, Lucas DM, Grever MR, Phelps MA, Chan KK: Characterization of silvestrol pharmacokinetics in mice using liquid chromatography-tandem mass spectrometry. AAPS J 2011, 13(3):347-356.

27. Garzon R, Croce CM: MicroRNAs in normal and malignant hematopoiesis. Curr Opin Hematol 2008, 15(4):352-358.

28. Lee DW, Futami M, Carroll M, Feng Y, Wang Z, Fernandez M, Whichard Z, Chen Y, Kornblau S, Shpall EJ, Bueso-Ramos CE, Corey SJ: Loss of SHIP-1 protein expression in high-risk myelodysplastic syndromes is associated with miR-210 and miR-155. Oncogene 2012, 31(37):4085-4094.

29. O'Connell RM, Rao DS, Chaudhuri AA, Boldin MP, Taganov KD, Nicoll J, Paquette RL, Baltimore D: Sustained expression of microRNA-155 in hematopoietic stem cells causes a myeloproliferative disorder. J Exp Med 2008, 205(3):585-594.

30. Garzon R, Volinia S, Liu CG, Fernandez-Cymering C, Palumbo T, Pichiorri F, Fabbri M, Coombes K, Alder H, Nakamura T, Flomenberg N, Marcucci G, Calin GA, Kornblau SM, Kantarjian H, Bloomfield CD, Andreeff M, Croce CM: MicroRNA signatures associated with cytogenetics and prognosis in acute myeloid leukemia. Blood 2008, 111(6):3183-3189.

31. Faraoni I, Laterza S, Ardiri D, Ciardi C, Fazi F, Lo-Coco F: MiR-424 and miR-155 deregulated expression in cytogenetically normal acute myeloid leukaemia: correlation with NPM1 and FLT3 mutation status. J Hematol Oncol 2012, 5:26.

32. Vigorito E, Perks KL, Abreu-Goodger C, Bunting S, Xiang Z, Kohlhaas S, Das PP, Miska EA, Rodriguez A, Bradley A, Smith KG, Rada C, Enright AJ, Toellner KM, Maclennan IC, Turner M: microRNA-155 regulates the generation of immunoglobulin class-switched plasma cells. Immunity 2007, 27(6):847-859.

33. Grosjean-Raillard J, Ades L, Boehrer S, Tailler M, Fabre C, Braun T, De Botton $\mathrm{S}$, Israel A, Fenaux P, Kroemer G: Flt3 receptor inhibition reduces constitutive NFkappaB activation in high-risk myelodysplastic syndrome and acute myeloid leukemia. Apoptosis 2008, 13(9):1148-1161.

34. Takahashi S, Harigae H, Ishii KK, Inomata M, Fujiwara T, Yokoyama H, Ishizawa K, Kameoka J, Licht JD, Sasaki T, Kaku M: Over-expression of Flt3 induces NF-kappaB pathway and increases the expression of IL-6. Leuk Res 2005, 29(8):893-899.

35. Dennis Gerloff DB-H, Katzerke C, Hartmann J-U, Mueller-Tidow C, Tenen DG, Niederwieser D, Behre G: FLT3-ITD Signaling Induces Oncogenic Mir-155 by NF-KB and STAT5 Pathways In Acute Myeloid Leukemia Thereby Targeting Transcription Factor PU.1. In 53rd ASH Annual Meeting and Exposition San Diego, California. 2011.

36. Baumann B, Bohnenstengel F, Siegmund D, Wajant $H$, Weber $C$, Herr I, Debatin KM, Proksch P, Wirth T: Rocaglamide derivatives are potent inhibitors of NF-kappa B activation in T-cells. J Biol Chem 2002, 277(47):44791-44800.

37. Alinari L, Prince CJ, Edwards RB, Towns WH, Mani R, Lehman A, Zhang X, Jarjoura D, Pan L, Kinghorn AD, Grever MR, Baiocchi RA, Lucas DM: Dual Targeting of the Cyclin/Rb/E2F and Mitochondrial Pathways in Mantle Cell Lymphoma with the Translation Inhibitor Silvestrol. Clin Cancer Res 2012, 18(17):4600-4611.

38. Kottaridis PD, Gale RE, Frew ME, Harrison G, Langabeer SE, Belton AA, Walker $H$, Wheatley K, Bowen DT, Burnett AK, Goldstone AH, Linch DC: The presence of a FLT3 internal tandem duplication in patients with acute myeloid leukemia (AML) adds important prognostic information to cytogenetic risk group and response to the first cycle of chemotherapy: analysis of 854 patients from the United Kingdom Medical Research Council AML 10 and 12 trials. Blood 2001, 98(6):1752-1759.

39. Pratz KW, Levis MJ: Bench to bedside targeting of FLT3 in acute leukemia. Curr Drug Targets 2010, 11(7):781-789.

40. Weisberg E, Barrett R, Liu Q, Stone R, Gray N, Griffin JD: FLT3 inhibition and mechanisms of drug resistance in mutant FLT3-positive AML. Drug Resist Updat 2009, 12(3):81-89.

41. Walters DK, Stoffregen EP, Heinrich MC, Deininger MW, Druker BJ: RNAiinduced down-regulation of FLT3 expression in AML cell lines increases sensitivity to MLN518. Blood 2005, 105(7):2952-2954.

42. Thompson RC, Herscovitch M, Zhao I, Ford TJ, Gilmore TD: NF-kappaB down-regulates expression of the B-lymphoma marker $\mathrm{CD} 10$ through a miR-155/PU.1 pathway. J Biol Chem 2011, 286(3):1675-1682.

43. Guzman ML, Neering SJ, Upchurch D, Grimes B, Howard DS, Rizzieri DA, Luger SM, Jordan CT: Nuclear factor-kappaB is constitutively activated in primitive human acute myelogenous leukemia cells. Blood 2001, 98(8):2301-2307.

44. Garzon R, Garofalo M, Martelli MP, Briesewitz R, Wang L, FernandezCymering C, Volinia S, Liu CG, Schnittger S, Haferlach T, Liso A, Diverio D, Mancini M, Meloni G, Foa R, Martelli MF, Mecucci C, Croce CM, Falini B: Distinctive microRNA signature of acute myeloid leukemia bearing cytoplasmic mutated nucleophosmin. Proc Natl Acad Sci U S A 2008, 105(10):3945-3950.

45. Inomata M, Takahashi S, Harigae H, Kameoka J, Kaku M, Sasaki T: Inverse correlation between Flt3 and PU.1 expression in acute myeloblastic leukemias. Leuk Res 2006, 30(6):659-664.

doi:10.1186/1756-8722-6-21

Cite this article as: Alachkar et al.: Silvestrol exhibits significant in vivo and in vitro antileukemic activities and inhibits FLT3 and miR-155 expressions in acute myeloid leukemia. Journal of Hematology \& Oncology 2013 6:21.

\section{Submit your next manuscript to BioMed Central and take full advantage of:}

- Convenient online submission

- Thorough peer review

- No space constraints or color figure charges

- Immediate publication on acceptance

- Inclusion in PubMed, CAS, Scopus and Google Scholar

- Research which is freely available for redistribution 